\title{
PENERAPAN TEKNOLOGI PENGENDALIAN PENYAKIT TANAMAN YANG RAMAH LINGKUNGAN PADA TEMBAKAU
}

\section{IMPLEMENTATION OF ENVIRONMENTALLY FRIENDLY PLANT DISEASE CONTROL TECHNOLOGY ON TOBACCO}

\author{
${ }^{1)}$ Endang Mugiastuti, ${ }^{2)}$ Loekas Soesanto dan ${ }^{3)}$ Abdul Manan \\ ${ }^{1,2,3)}$ Fakultas Pertanian, Universitas Jenderal Soedirman \\ Jl. Dr. Suparno, Karangwangkal. \\ Purwokerto 53123, Telp./faks. 0281-638791 \\ Alamat korespondensi: endangmugiastuti@gmail.com
}

\begin{abstract}
ABSTRAK
Tembakaumerupakan salah satu tanaman unggulan yang penting yang banyak dibudidayakan oleh Kelompok Tani "Darma Mukti Tani I" dan Kelompok Tani "Karya Tani” Kecamatan Wangon, Kabupaten Banyumas. Namun beberapa kendala sering mengganggu produksi tanaman tembakau, di antaranya hama dan penyakit tanaman tembakauyang cukup tinggi. Sosialisasi pengelolaan hama dan penyakit tanaman tembakau dengan menggunakan biopestisida Trichoderma sp., dan Pseudomonas fluorescens perlu dilakukan. Tujuan kegiatan adalah meningkatkan pengetahuan dan keterampilan petani tentang hama dan penyakit pada tanaman tembakauserta tindakan pengelolaannya dengan pestisida hayati. Permasalahan mitra diatasi dengan beberapa pemecahan teknologi, yang dilakukan dengan metode transfer teknologi melalui pendidikan, pelatihan, demplot, dan pendampingan. Kegiatan sosialisasi mampu meningkatkan pengetahuan petani tentang jenis hama dan penyakit,pengendaliannya, dan pengendalian yang ramah lingkungan masing-masing sebesar 58,82, 62,5, dan 67,67\%. Kegiatan pelatihan eksplorasi P. fluorescens mampu meningkatkan kemampuan petani166,67\%. Kegiatan pelatihan perbanyakan dan aplikasi mampu meningkatkan kemampuan petani masing-masing sebesar 100 dan 73,33\%. Kegiatan pelatihan eksplorasi Trichoderma sp. mampu meningkatkan kemampuan petani 94,44\%, sedangkan kegiatan pelatihan perbanyakan dan aplikasi mampu meningkatkan kemampuan petani masing-masing sebesar 73,33 dan 88,23\%. Aplikasi pestisida hayati P. fluorescens dan Trichoderma sp. pada petak demplot mampu meningkatkan pertumbuhan tanaman tembakau dan menurunkan intensitas penyakit layu bakteri dan fusarium sebesar 40-50\%.
\end{abstract}

Kata kunci: Tembakau, Transfer Teknologi, Hama Dan Penyakit, Pengendalian Hayati.

\section{ABSTRACT}

Tobacco is one of the most important plants which were cultivated by Farmers Groups "Darma Mukti Tani I" and "Karya Tani" of Wangon District, Banyumas Regency. However, several obstacles often interfere with the production of tobacco, including quite high tobacco pests and diseases. Socialization of plant pests diseases management by using Trichoderma sp. and Pseudomonas fluorescens biopesticides, needs to be done. The activity aimed was to increase knowledge and skills of farmers on pests and diseases in tobacco and their management measures with biological pesticides. Issues addressed farmers partners with several technology solution, which was conducted by the transfer of technology through education, training, demonstration plots, and mentoring. Dissemination activities were able to increase their knowledge of pests and diseases, their control, and the control of environmental friendly as 58,82, 62,5, and 67.67\%, respectively. The training activities of P. fluorescens exploration was able to improve their ability as $166.67 \%$. Propagation activity and application training could improve their ability for 100 and 73,33\%, respectively. The training activities of Trichoderma sp. exploration were able to improve their ability as 94,44\%, while the propagation and application training could improve their ability, respectively, as 73,33 and $88.23 \%$. Application of biological pesticides $P$. fluorescens and Trichoderma sp. at demonstration plot was able to increase growth and reduced the intensity of bacterial and fusarium wilt disease by $40-50 \%$.

Keywords : Tobacco, Technology Transfer, Pests And Diseases, Biological Control. 


\section{PENDAHULUAN}

Tembakau (Nicotiana tabacum) merupakan salah satu tanaman unggulan yang penting di Indonesia, dan mendapat perhatian dari berbagai pihak, khususnya terkait dengan cukai dan pajak eksport tembakau cukup besar. Tembakau banyak dimanfaatkan untuk industri rokok, namun di masa mendatang tembakau mempunyai prospek dimanfaatkan sebagai bahan baku obat dan pestisida. Indonesia merupakan salah satu negara dari 10 negara penyuplai tembakau terbesar, dan berada di posisi kelima dengan kontribusi sebesar 2,59\% atau sebesar 184.309 ton (Kementerian Pertanian, 2014). Prospek pasar tembakau di luar negeri masih cukup baik, sehingga ada peluang menambah eksport tembakau. Peningkatan kebutuhan tembakau perlu diikuti oleh peningkatan hasil dan kualitas tanaman pada budidaya tembakau.

Sebagian besar budidaya tembakau di Indonesia berada di tiga propinsi, yaitu Jawa Tengah, Jawa Timur dan Nusa Tenggara. Pada tahun 2014, Jawa Tengah merupakan daerah dengan luas tanam terbesar ke-2 di Indonesia yaitu mencapai 40.620 ha, di bawah Jawa Timur yang mencapai 83.386 ha (Direktorat Jenderal Perkebunan, 2014).Sebanyak 22 k'abupaten/kota menjadi sebaran perkebunan tembakau di Jawa Tengah, termasuk Kabupaten Banyumas. Kabupaten Banyumas cukup potensial untuk pengembangan tanaman tembakau (Setiadji, et al.,2009) khususnya di DAS Serayu, seperti Kecamatan Rawalo, Kebasen dan Wangon. Tembakau telah dibudidayakan di Kabupaten Banyumas sejak puluhan tahun silam, atau sekitar 50 sampai 65 tahun silam. Luas lahan tembakau yang berproduksi adalah 60,75 $\mathrm{Ha}$, sedang yang tidak berproduksi adalah $0,50 \mathrm{Ha}$, sehingga jumlah total luas lahan tanaman tembakau adalah 61,25 $\mathrm{Ha}$, dengan produksi tembakau rajangan sebesar 33,18 ton daun kering, sehingga rata-rata produksi tembakau rajangan adalah $540 \mathrm{~kg}$ daun kering/ha (Dinas Perkebunan dan Kehutanan Kabupaten Banyumas, 2015).

Kelompok Tani “Darma Mukti Tani I", Desa Klapagading Kulon dan Kelompok Tani "Karya Tani" Desa Pengadegan, Kecamatan Wangon merupakan kelompok tani yang secara intensif mengembangkan budidaya tanaman tembakau sejak puluhan tahun yang lalu sebagai salah satu tambahan penghasilan, disamping membudidayakan tanaman padi sebagai makanan pokok serta berbagai tanaman palawija dan sayuran.Kelompok tani tersebut mengusahakan tembakau secara turun temurun.Budidaya tembakau biasanya dilakukan pada akhir musim penghujan hingga musim kemarau. Secara umum usaha budidaya tembakau di kedua kelompok tani sudah berjalan cukup baik. Namun terdapat beberapa kendala yang sering mengganggu pertumbuhan dan hasil tanaman tembakau. Kejadian penyakit pada tanaman tembakau di kedua kelompok tani tersebut cukup tinggi, yaitu berkisar 20-70 \%. Hal ini dikarenakan pengetahuan tentang penyebab penyakit pada tanaman tembakau serta pengelolaaannya pada umumnya masih sangat rendah. Selama ini anggota kelompok tani selalu menggunakan pestisida sintetis, yang tidak murahdan jika tidak dilakukan dengan bijaksana juga dapat menimbulkan pengaruh negatif bagi lingkungan. Disamping itu, tindakan pengelolaan penyakit pada tanaman tembakau belum memberikan hasil yang memuaskan. Penggunaan pestisida sintesis (fungsida dan bakterisida) tidak cukup efektif untuk mengendalikan penyakit, khususnya penyakit yang disebabkan patogen tular-tanah. 
Bertitik tolak dari uraian di atas, maka dilakukan sosialisasi perbaikan dalam kegiatan dalam budidaya tanaman tembakau khususnya dalam pengelolaan penyakit tanaman tembakau dengan menggunakan biopestisida Trichodermasp., dan P. fluorescens, yang ramah lingkungan dan memungkinkan dibuat sendiri oleh petani.

Adapun tujuan dari kegiatan adalah meningkatkan pengetahuan dan keterampilan petani tentang penyakit pada tanaman tembakau serta tindakan pengelolaannya yang efektif, efisien, murah dan ramah lingkungan dengan menggunakan pestisida hayati; dan meningkatkan pendapatan petani tanaman tembakau melalui peningkatan efisiensi usahatani. Manfaat yang diharapkan dari kegiatan ini adalah adanya penyelamatan dan peningkatan produksi tanaman tembakau, peningkatkan motivasi untuk pengembangan usaha meningkat, terjadinya efisiensi usahatani yang signifikan, dan peningkatan penyerapan tenaga kerja.

\section{METODE}

\section{a. Pemilihan mitra}

Mitra dari kegiatan ini adalah kelopok tani "Darma Mukti Tani I" dan Kelompok Tani "Karya Tani", Kecamatan Wangon, Kabupaten Banyumas. Pemilihan kelompok tani ini didasarkan pada kelompok tani yang secara intensif mengembangkanbudidaya tanaman tembakau dan adanya permasalahan yang perlu dibantu pemecahaannya.

\section{b. Alih Teknologi}

Permasalahan mitra diatasi dengan beberapa pemecahan teknologi, yangdilakukan dengan metode transfer teknologi melalui pendidikan, pelatihan, demplot, dan pendampingan. Metode pendidikan melalui ceramah dan diskusi dilakukan sebagai media alih teknologi yang bersifat interaktif dan berlangsung dua arah. Tolok ukur peningkatan pengetahuan dilakukan dengan melakukan pre-test sebelum mengikuti ceramah, dan setelah mengikuti kegiatan ceramah dilakukan post-test. Peningkatan pengetahuan didapatkan dengan membandingkan kedua hasil test tersebut.

Penerapan program dilanjutkan dengan peningkatan ketrampilan petani melalui melalui kegiatan pelatihan secara demonstrasi dengan melibatkan seluruh peserta secara aktif. Kegiatan pelatihan meliputi isolasi Trichoderma sp. dan Pseudomonas kelompok fluorescens; perbanyakan dan pembuatan biopestisida berbahan aktif Trichoderma sp. dan Pseudomonas sp. dengan medium cair (Soesantoet al. 2009, 2011, 2014). Peningkatan ketrampilan peserta diukur dengan mengamati jumlah peserta yangmampu membuat biopestisida dengan baik dan benar.

\section{c. Demplot}

Kegiatan penyuluhan dan pelatihan dilanjutkan dengan demplot budidaya tanaman tembakausebagai sarana praktek pengelolaan penyakit pada tanaman tembakau. Demplot menggunakan petakan lahan. Satu petak merupakan demplot teknologi budidaya tanaman tembakau yang dikelola dengan kultur teknis yang baik (Balai Penelitian Tanaman Pemanis dan Serat, 2017), dengan memanfaatkan dan mengembangkan potensi yang ada, termasuk pemupukan dan pengendalian penyakit yang ramah lingkungan dengan memanfaatkan biopestsida Trichodermasp. dan Pseudomonas fluorescens. Satu petak yang lain sebagai pembanding menggunakan teknologi pembimbitan yang bisa digunakan kelompok tani mitra yaitu menggunakan pestisida kimia sintetik. Hasil kedua petak tersebut diamati intensitas penyakit dan hama, serta pertumbuhannya, kemudian dilakukan analisis ekonominya. 


\section{HASIL DAN PEMBAHASAN}

\section{a. Sosialisasi hama dan penyakit pada tanaman tembakau dan usaha pengendalian yang efektif, efisien, murah, dan ramah lingkungan}

Kegiatan sosialisasi dilakukan di rumah ketua kelompok tani Darma Mukti Tani I,diikuti anggota kelompok tani mitra (Gambar 1). Sosialisasi meliputi pengenalan gejala dan pengelolaan hama dan penyakit pada tanaman tembakau, serta berbagai faktor yang mendukung perkembangan hama dan penyakit. Kegiatan sosialisasi dilaksanakan dengan metode ceramah dan pengenalan langsung di kebun petani. Penyakit yang banyak ditemukan dan menjadi masalah di tanaman tembakau di antaranya penyakit layu bakteri (Ralstonia solanacearum.), penyakit layu Fusarium(Fusarium sp.) dan penyakit karena virus. Hama yang banyak ditemukan ulat pemakan daun (Spodoptera sp. dan Helicoverpa sp.) dan kutu daun.

Tabel 1. Tingkat pengetahuan petani tentang jenis dan pengendalian hama dan penyakit pada tanaman tembakau

\begin{tabular}{|c|c|}
\hline Pengetahuan petani & $\begin{array}{l}\text { Peningkatan } \\
\text { pengetahuan } \\
(\%)\end{array}$ \\
\hline Jenis hama dan penyakit tembakau & 58,82 \\
\hline Pengendalian hama dan penyakit tembakau & 62,5 \\
\hline $\begin{array}{l}\text { Pengendalian hama dan penyakit tembakau } \\
\text { ramah lingkungan }\end{array}$ & 67,67 \\
\hline $\begin{array}{l}\text { Kegiatan } \begin{array}{c}\text { sosialisasi } \\
\text { pengetahuan }\end{array} \\
\text { meningkatkan } \begin{array}{r}\text { anggota } \\
\text { kelompok tani tentang hama } \\
\text { danpenyakit } \\
\text { pada tanamantembakau dan pentingnya }\end{array} \\
\text { tindakan pengendalian yang efektif, efisien, } \\
\text { ramah lingkungan dan lestari (Tabel 1). } \\
\text { Selama ini, pengenalan gejala hama dan } \\
\text { penyakit tanaman tembakau oleh petani } \\
\text { masih rendah, yaitu hanya sekitar 42,5\%. } \\
\text { Petani umumnya tidak dapat membedakan }\end{array}$ & $\begin{array}{l}\text { sesuai dengan pendapat Lumintang (2013), } \\
\text { yang mengatakan bahwa biaya produksi } \\
\text { berpengaruh terhadap pendapatan petani } \\
\text { dalam pengelolahan usahatani. Lebih lanjut } \\
\text { dikatakan bahwa pendapatan merupakan } \\
\text { salah satu indikator peningkatan } \\
\text { kesejahteraan seseorang atau masyarakat, } \\
\text { sehingga pendapatan masyarakat ini } \\
\text { mencerminkan kemajuan ekonomi suatu } \\
\text { masyarakat. }\end{array}$ \\
\hline
\end{tabular}
jenis organisme pengganggu tanaman (OPT) yang menyerang tanaman tembakau mereka. Hal ini berakibat pada kurang dilakukan tindakan pengendalian OPT dengan baik, yaitu hanya $40 \%$, sehingga banyak tanaman tembakau yang mengalami kematian dan terjadi penurunan produksi. Pengetahuan petani tanaman tembakau terhadap Kegiatan sosialisasi mampu meningkatkan pengetahuan petani tentang jenis hama dan penyakit sebesar 58,82\%, pengendalian hama dan penyakit tembakau $62,5 \%$, serta pengendalian hama dan penyakit yang ramah lingkungan sebesar 67,67\% (Tabel 1).

pengendalian hama dan penyakit yang ramah lingkungan juga masih rendah, hanya $30 \%$. Hal ini menyebabkan tingginya pengeluaran mereka untuk biaya produksi, khususnya untuk pembelian pestisida, dan menyebabkan menurunnya pendapatan mereka. Hal ini 

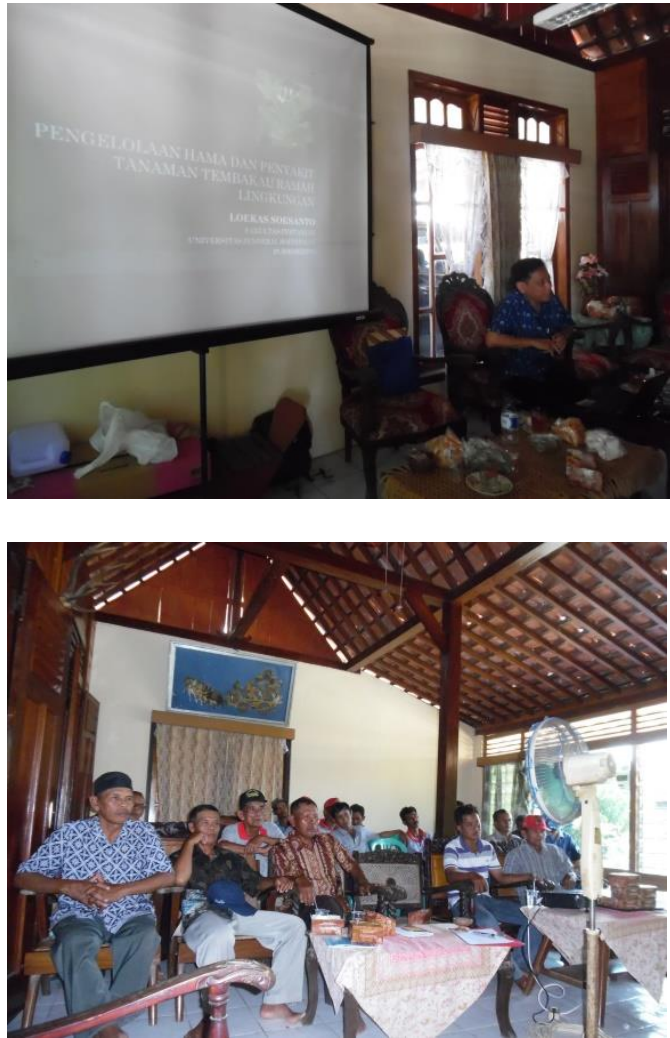

Gambar 1. Sosialisasi hama dan penyakit pada tanaman tembakau dan usaha pengendalian yang efektif, efisien, murah, dan ramah lingkungan.

\section{b. Sosialisasi potensi, pelatihan perbanyakan dan aplikasi pestisida hayati berbasis $\boldsymbol{P}$. fluorescens P60untuk mengendalikan penyakitpada tanaman tembakau}

Kegiatan sosialisasi dan pelatihan pestisida hayati berbasis P. fluorescens P60 untuk mengendalikan penyakit pada tanaman tembakau dilaksanakan di rumah Ketua Kelompok Tani Darma Mukti Tani I diikuti oleh anggota kelompok tani mitra. Pada kegiatan ini, dilakukan penyuluhan tentang pentingnya penggunaan pestisida hayati untuk menjaga kelestarian lingkungan hidup serta ditunjukkan kemampuan biopestisida berbasis $P$. fluorescensP60. dalam menekan perkembangan penyakit tanaman dan meningkatkan pertumbuhan tanaman.

P. flourescens P60 termasuk strain
bakteri antagonis yang telah diteliti

kemampuannya di dalam mengendalikan beberapa patogen tanaman, khususnya patogen tular-tanah, baik secara in vitro, in planta maupun in vivo (Soesanto, 2013). Bakteri ini mampu mengoloni daerah perakaran dalam jumlah populasi yang stabil. Antagonis ini mampu menghasilkan beberapa jenis antibiotik. $P$. fluorescens mampu menghasilkan antibiotika antara lain phenazine-1-carbocylic acid (P1C), $\mathrm{HCN}$, dan 2,4 diacethylphloroglucinol (Raaijmakers and Weller, 1998; Soesanto, 2000; Ahmadzadeh dan Tehrani, 2009). Berbagai penelitian telah dilakukan terhadap kemampuannya untuk mengendalikan penyakit tanaman, termasuk untuk mengendalikan penyakit pada tanaman pisang (Soesanto dan Rahayuniati, 2009). Selain itu, bakteri tersebut juga berfungsi sebagai PGPR (Plant Growth Promoting Rhizobacteria) atau perangsang pertumbuhan tanaman dan meningkatkan kelarutan unsur fosfat (Soesanto, et al., 2009; 2010). Selain itu, $P$. flourescens P60 juga mampu menghasilkan siderofor yang mampu mengikat zat besi pada tanah yang kekurangan zat besi, sehingga unsur ini tersedia bagi tanaman.

Selanjutnya petani dilatih untuk memperbanyak dan membuat biopestisida dengan cara yang sederhana yaitu dalam medium kaldu keong dan terasi (Gambar 2). Petani juga diajarkan untuk mendapatkan (mengeksplorasi) bakteri antagonis dari alam, yaitu dari rhizosfer tanaman putri malu. Disamping pelatihan perbanyakan, juga petani dilatih mengenai cara aplikasi biopestisida tersebut melalui kegiatan demplot. Dokumentasi kegiatan seperti Gambar 2.

Kegiatan sosialisasi serta pelatihan perbanyakan dan aplikasi pestisida hayati berbasis $P$. fluorescens, mampu meningkatkan pengetahuan dan ketrampilan anggota kelompok tani (Tabel 2). Kegiatan sosialisasi mampu meningkatkan pengetahuan petani tentang manfaat $P$. fluorescenssebesar $78,57 \%$. Kegiatan pelatihan eksplorasi mampu meningkatkan kemampuan petani 166,67\%.Kegiatan pelatihan perbanyakan mampu meningkatkan kemampuan petani sebesar $100 \%$ dan pelatihan aplikasi mampu meningkatkan kemampuan aplikasi 85,71\%.

Tabel 2. Tingkat pengetahuan dan ketrampilan petani tentang pestisida hayati berbasis $P$. fluorescens 


\begin{tabular}{llll}
\hline Pengetahuan dan Ketrampilan petani & $\begin{array}{l}\text { Sebelum } \\
\text { kegiatan }\end{array}$ & $\begin{array}{c}\text { Sesudah } \\
\text { kegiatan }\end{array}$ & $\begin{array}{c}\text { Peningkatan } \\
\text { pengetahuan/ } \\
\text { ketrampilan(\%) }\end{array}$ \\
\hline Manfaat $P$. fluorescens, & 35 & 60 & 71,42 \\
EksplorasiP. fluorescens & 15 & 40 & 166,67 \\
Perbanyakan P. fluorescens & 30 & 60 & 100 \\
Aplikasi $P$. fluorescens & 37,5 & 65 & 73,33 \\
\hline
\end{tabular}
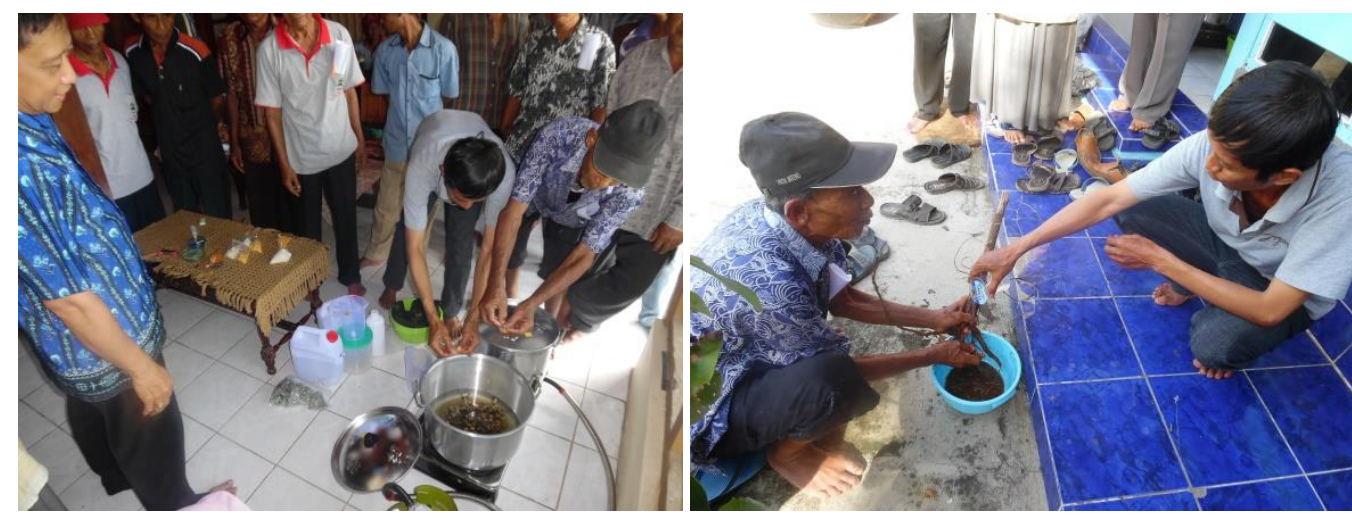

Gambar 2. Sosialisasi potensi, pelatihan perbanyakan dan aplikasi pestisida hayati berbasis $P$. fluorescens P60 untuk mengendalikan penyakit pada tanaman tembakau.

c. Sosialisasi potensi, pelatihan perbanyakan dan aplikasi pestisida hayati berbasis Trichoderma sp. untuk mengendalikan penyakit tanaman pada tanaman tembakau

Kelompok tani juga dilatih teknik perbanyakan Trichoderma sp. Trichodermasp. merupakan jamur yang mudah diisolasi dari berbagai tempat dan telah diuji keberhasilanya untuk mengendalikan berbagai patogen pada berbagai tanaman khususnya yang berada di dalam tanah. T. harzianum mampu menunda masa inkubasi dan menurunkan intensitas penyakit layu Fusarium, dan mengendalikan Phytophtrora capsici (Rahayuniati dan Mugiastuti, 2009; Rahayuniati dan Kurniawan, 2009). Trichoderma sp. juga dilaporkan mampu menurunkan jumlah sista nematoda Globodera rostochiensis sampai 49\% (Manan dan Mugiastuti, 2005). Di samping sebagai agensia hayati, Trichodermasp. juga mempunyai sifat sebagai dekomposer, yang membantu dekomposisi bahan organik menjadi nutrisi yang dapat dimanfaatkan oleh tanaman (Widyastuti, 2004).
Perbanyakan Trichoderma sp. dilakukan dalam padat dan medium cair, yaitu air cucian beras dan air kelapa yang murah dan mudah diterapkan. Peralatan yang digunakan cukup sederhana, dan tersedia di masyarakat, yaitu jerigen, panci, saringan, dan kompor. Disamping perbanyakan dari biakan murni, petani juga diajarkan cara mengekplorasi Trichoderma sp. dari lapang, dengan menggunakan kelapa yang ditanam dalam tanah, selama 5-7 hari (Gambar 3).Eksplorasi berhasil jika kelapa ditumbuhi jamur berwarna hijau (Trichoderma sp.). Pelatihan dilanjutkan dengan teknik aplikasinya di lapang (Gambar 4).

Kegiatan sosialisasi mampu meningkatkan pengetahuan petani tentang manfaat pestisida hayati sebesar $62,50 \%$. Kegiatan pelatihan eksplorasi mampu meningkatkan kemampuan petani 94,44 \%, kegiatan pelatihan perbanyakan mampu meningkatkan kemampuan petani sebesar $73.33 \%$ dan pelatihan aplikasi mampu meningkatkan kemampuan aplikasi 88,23\%. 
Tabel 3. Tingkat pengetahuan dan ketrampilan petani tentang pestisida hayati berbasis Trichoderma

\begin{tabular}{llll}
\multicolumn{1}{c}{ sp. } & Sebelum \\
Pegiatan & $\begin{array}{l}\text { Sesudah } \\
\text { kegiatan }\end{array}$ & $\begin{array}{l}\text { Peningkatan } \\
\text { pengetahuan/ } \\
\text { ketrampilan(\%) }\end{array}$ \\
\hline Manfaat jamur Trichoderma sp. & 40 & 65 & 62,50 \\
EksplorasiTrichoderma sp & 18 & 35 & 94,44 \\
Perbanyakan Trichoderma sp. & 30 & 52 & 73,33 \\
Aplikasi Trichoderma sp. & 34 & 64 & 88,23 \\
\hline
\end{tabular}

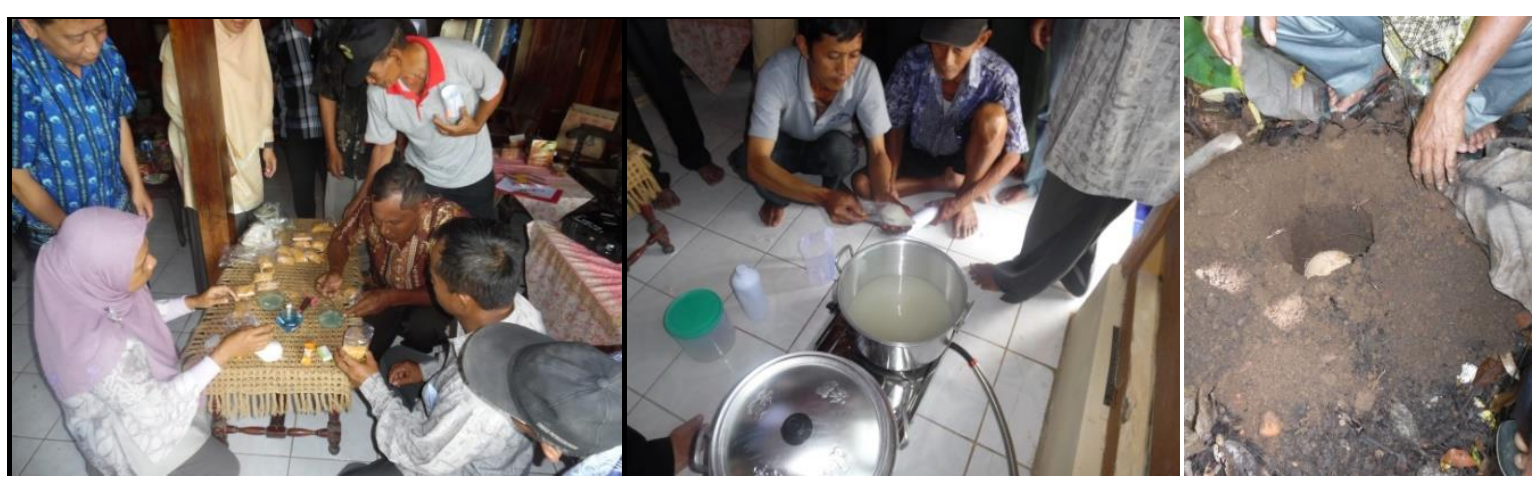

Gambar 3. Sosialisasi potensi, pelatihan perbanyakan dan aplikasi pestisida hayati berbasis Trichoderma sp. untuk mengendalikan penyakit pada tanaman tembakau

\section{d. Pembuatan demplot teknologi budidaya tanaman tembakau dengan paket teknologi ramah lingkungan dan pendampingan petani dalam melaksanakan paket teknologi}

Demplot teknologi dibuat sebagai percontohan untuk petani dengan tujuan agar petani dapat lebih memahami dan menghayati pelatihan yang diberikan, serta dapat mengambil keputusan terhadap langkah pengelolaan penyakit pada tanaman tembakau pada lahan pertanian masing-masing. Demplot dilaksanakan pada lahan anggota kelompok tani Darma Mukti Tani I. Demplot dibedakan dalam dua kelompok, kelompok I menggunakan paket teknologi yang biasa dilakukan oleh petani, yaitu penggunaan pupuk anorganik dan paket pengendalian dengan pestisida sintetis. Kelompok tanaman II, menggunakan paket teknologi yang diperkenalkan oleh tim yaitu dengan menggunakan pupuk organik yang diperkaya mikroba antagonis, biopestisida
Trichodermasp. dan Pseudomonas fluorescens, Dokumentasi kegiatan seperti pada Gambar 4.

Kegiatan demplot, dengan menerapkan paket teknologi budidaya yang ramah lingkungan, diperoleh hasil seperti Tabel 4. Berdasarkan hasil tersebut, nampak bahwa terjadi peningkatan pertumbuhan pada tanaman tembakau yang dibudidayakan menggunakan paket teknologi menggunakan pestisida hayati. Hal ini karena $P$. fluorescens, dan Trichoderma sp.yang ditambahkan pada saat tanam menghasilkan PGPR yang mampu mendorong peningkatan pertumbuhan vegetatif tanaman, meningkatkan jumlah daun dan tinggi tanaman tembakau jika dibandingkan dengan petak petani. Daun juga mempunyai ukuran yang lebih besar.PGPR ini berperan dalam meningkatkan pertumbuhan dan perkembangan tanaman. Hal ini sesuai dengan hasil penelitian Santosoet al. (2007) dan Soesanto, et al. (2010). 
Tabel 3. Pertumbuhan dan intensitas penyakit pada tanaman tembakau

\begin{tabular}{llll}
\hline No & \multicolumn{1}{c}{$\begin{array}{c}\text { Pertumbuhan tanaman dan intesitas } \\
\text { penyakit pisang }\end{array}$} & $\begin{array}{c}\text { Petak demplot } \\
\text { petani }\end{array}$ & Petak demplot teknologi \\
\hline 1 & Jumlah Daun (lembar) & $6-7$ & $10-11$ \\
2 & Tinggi Tanaman (cm) & $60-70$ & $85-100$ \\
3 & PenyakitLayu Fusarium(\%) & 10 & 5 \\
4 & Penyakit Layu bakteri (\%) & 17 & 10 \\
5 & Penyakit Karena Virus (\%) & 30 & 28 \\
\hline
\end{tabular}

Selain pertumbuhan tanaman, diamati pula persentase intensitas penyakitnya. Berdasarkan pengamatan, intensitas penyakit layu fusariumdan layu bakteri pada demplot petani berturut-turut mencapai $10 \%$ dan 17 , sedangkan pada demplot teknologi hanya 5\% dan $10 \%$ atau dapat menurunkan intensitas penyakit sebesar $50 \%$ dan $41 \%$. Hal ini dipengaruhi oleh keberadaan mikroba yang terdapat dalam pestisida hayati. Mikroba Trichoderma sp. dan P.fluorescens diketakui mampu menekan patogen melalui berbagai mekanisme diantaranya persaingan ruang atau nutrisi dan menghasilkan senyawa antibiotika ataupun senyawa toksin lain (Soesanto, 2013). Selain itu, mikroba-mikroba tersebut mampu mengimbas ketahanan tanaman.

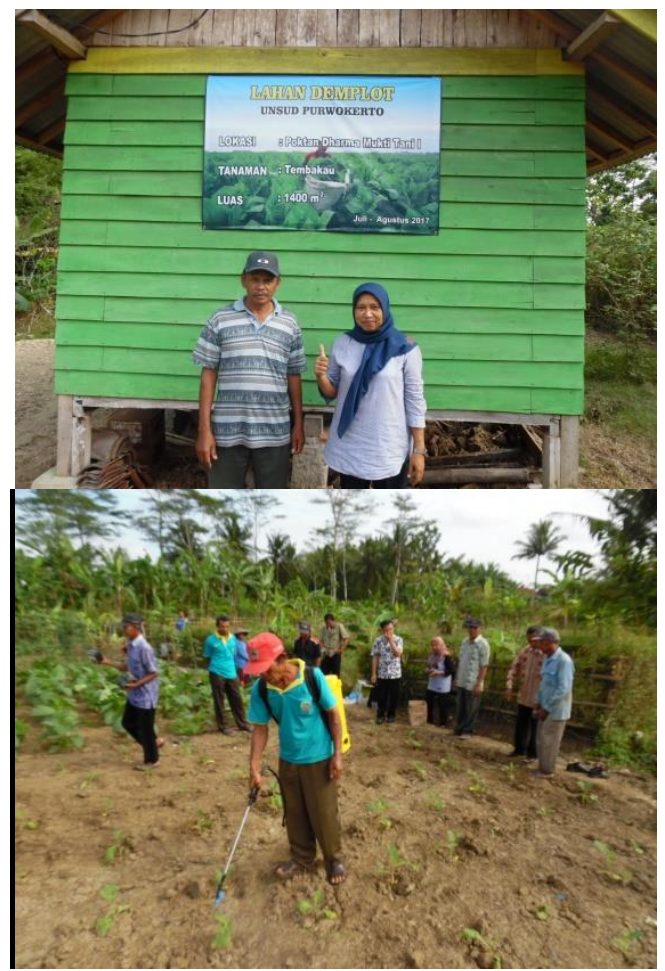

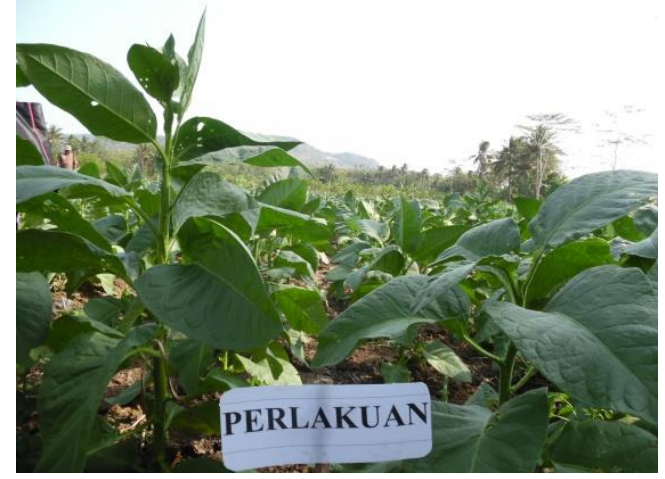

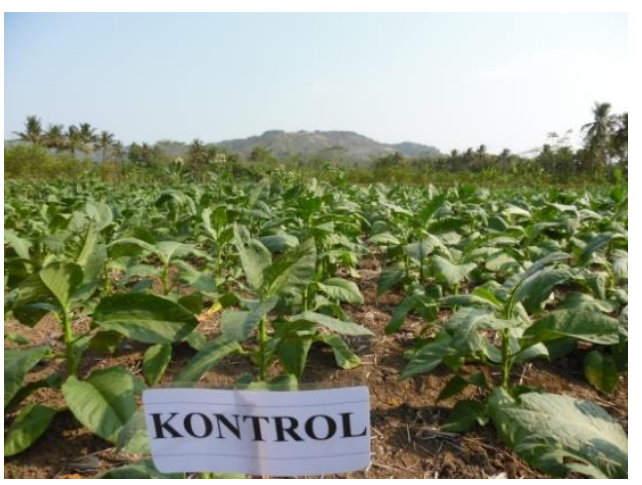

Gambar 4. Aplikasi dan pengamatan teknologi pengendalian hayati pada tanaman tembakau.

Penyakit virus yang diamati intensitas penyakitnya belum nampak perbedaan yang berarti yaitu sekitar $30 \%$ pada kedua demplot.Penyakit ini sangat dipengaruhi keberadaan vektor, seperti berbagai jenis kutu yang menyerang tanaman. Aplikasi Pseudomonas sp. dan Trichoderma sp. belum banyak pengaruhnya terhadap ketahanan tanaman terhadap serangan hama.

\section{SIMPULAN}

Kegiatan sosialisasi dan pelatihan mampu meningkatkan pengetahuan dan ketrampilan petani tentang hama dan penyakit 
pada tanaman tembakau dan upaya pengelolaannya yang ramah lingkungan, dengan menggunakan Trichoderma sp, dan Pseudomonas fluorescens. Aplikasi pestisida hayati P. fluorescens dan Trichodermasp. Pada petak demplot mampu meningkatkan pertumbuhan tanaman tembakau dan menurunkan intensitas penyakit layu bakteri dan fusarium sebesar $40-50 \%$.

\section{UCAPAN TERIMA KASIH}

Terima kasih kepada Direktorat Penelitian dan Pengabdian Kepada Masyarakat, Direktorat Jenderal Pendidikan Tinggi, Kementerian Riset dan Pendidikan Tinggi, atas dukungan pendanaannya melalui Hibah IbM, juga kepada semua anggota Kelompok Tani Darma Mukti Tani I dan Karya Tani, Kecamatan Wangon, Kabupaten Banyumas atas kerjasamanya yang terjalin baik.

\section{DAFTAR PUSTAKA}

Ahmadzadeh, M. \&Tehrani, A.S. (2009). Evaluation of fluorescent pseudomonads for plant growth promotion, antifungal activity against Rhizoctonia solani on common bean, and biocontrol potential, Biological Control 48(2):101-107.

Balai Penelitian Tanaman Pemanis dan Serat. (2017). Budidaya Tembakau Temanggung. Online. http://perkebunan.litbang.pertanian.go.id/?p=17 $\underline{679}$ diakses tanggal 2 September 2017

Dinas Perkebunan dan Kehutanan Kabupaten Bayumas. (2015). Luas dan Produksi Tanaman Perkebunan di Kabupaten Banyumas.

Direktorat Jenderal Perkebunan. (2014). Statistik Perkebunan Indonesia 20132015. Tembakau. Direktorat Jenderal Perkebunan, Jakarta.

Kementerian Pertanian. (2014). Outlook Komoditi Tembakau. Sekretariat
Jenderal Kementerian Pertanian, Jakarta.

Lumintang, F.M. (2013). Analisis pendapatan petani padi di Desa Teep Kecamatan Langowan Timur. Jurnal EMBA 1(3): 991-998.

Manan, A. \& E. Mugiastuti. (2005). Potensi Jamur parasit dan pestisida Nabati Untuk Mengendalikan nematoda Globodera rostochiensis Pada Tanaman Kentang. Laporan Penelitian. Fakultas Pertanian Unsoed, Purwokerto.

Raaijmakers, J.M. \& Weller, D.M.. (1998). Natural plant protection by 2,4diacetylphloroglucinol-producing Pseudomonas spp. In take-all decline soils. Molecular Plant-Microbe Interactions 11:144-152.

Rahayuniati, R.F. \& Kurniawan, R.E.K. (2008). Ketahanan Tanaman Lada Terhadap Penyakit Busuk Pangkal Batang: Aplikasi Bahan Organik dan Jamur Antagonis. Laporan Penelitian Dosen Muda. Dikti.

Rahayuniati, R.F. \& Mugiastuti E. (2009). Pemanfaatan Jamur Antagonis dan Pupuk Organik Untuk Mengendalikan Penyakit layu Fusrium Tomat. Jurnal Pembangunan Pedesaan 9(1).

Santoso, S.E., Soesanto L. \& Haryanto, T.A.D. (2007). Penekanan hayati penyakit moler pada bawang merah dengan Trichodermaharzianum,

Trichodermakoningii, dan Pseudomonas fluorescens P60. Jurnal Hama dan Penyakit Tumbuhan Tropika 7(1): 5361.

Setiadji, B., Maryanto, J., Susilo, B.S., Rif'an, M., \& B. Warsito. (2009). Studi Potensi Lahan untuk Pengembangan Tanaman Tembakau dan Cengkeh di Kabupaten Banyumas. Laporan Hasil Penelitian. Fakultas Pertanian Unsoed Purwokerto

Soesanto, L. (2000). Ecological and Biological Control of Verticillium dahliae. Ph.D. Thesis. Wageningen University, Wageningen. $120 \mathrm{p}$. 
Soesanto, L. (2013). Pengantar Pengendalian Hayati Penyakit Tanaman. PT. Raja Grafindo Persada. Jakarta.

Soesanto, L. \&Rahayuniati, R.F. (2009). Pengimbasan ketahanan bibit pisang Ambon Kuning terhadap penyakit layu Fusarium dengan beberapa jamur antagonis. Jurnal HPT Tropika 9(2): 130-140.

Soesanto, L., Mugiastuti, E.\&Rahayuniati, R.F. (2009). Perakitan Biopestisida Pseudomonas fluorescens P60 sebagai Agensia Hayati Penyakit Tanaman untuk Meningkatkan Produksi Tanaman. Laporan Penelitian Hibah Kompetensi Tahun I. Universitas Jenderal Soedirman, Purwokerto.

Soesanto, L., Mugiastuti,E.\&Rahayuniati R.F. (2010). Kajian mekanisme antagonis Pseudomonasfluorescens P60 terhadap Fusarium oxysporumf.sp. lycopersici pada tanaman tomat in vivo. Jurnal
Hama dan Penyakit Tumbuhan Tropika 10(2): 108-115.

Soesanto, L., Mugiastuti, E.\&Rahayuniati, R.F. (2011). Perakitan Biopestisida Pseudomonas fluorescens P60 sebagai Agensia Hayati Penyakit Tanaman untuk Meningkatkan Produksi Tanaman. Laporan Penelitian Hibah Kompetensi Tahun III. Universitas Jenderal Soedirman, Purwokerto.

Soesanto, L., Mugiastuti, E. \& Prakoso, B. (2014). Perakitan Biopestisida Trichoderma spp.sebagai Agensia Hayati Penyakit Tanaman untuk Meningkatkan Produksi Tanaman. Laporan Penelitian Hibah Kompetensi Tahun II. Universitas Jenderal Soedirman, Purwokerto.

Widyastuti, S.M. (2004). Pengembangan dan Aplikasi Mikroba Antagonis dari Patogen Tumbuhan. Makalah Pelatihan Pengendalian Hayati, UM, Yogyakartta 